\title{
Review: Assessment of cell proliferation in histological material
}

\author{
P A Hall, D A Levison
}

\section{Introduction}

There can be little dispute that cellular proliferation is one of the most fundamental of biological processes. ${ }^{1}$ Nor can there be disagreement over the importance of assessing cellular proliferation in the study of many biological processes: indeed, Leblond ${ }^{2}$ used such assessment for identifying the three major functional types of cellular populationnamely, static, conditional renewal, and continually renewing. The practice of histopathology involves direct or, more usually, indirect assessment of cellular proliferation (and related phenomena such as differentiation) in many situations. $^{3}$ It is intended that this brief overview will illustrate current ideas about cellular proliferation and its regulation and the advantages and disadvantages of the better known methods for assessing cellular proliferation in histopathological material

The cell cycle

The observations of Howard and Pelc, who used ${ }^{32} \mathrm{P}$ incorporation and autoradiography during the early 1950 s, led to the introduction of the concept of the cell cycle and its subdivision into several phases (figure). ${ }^{45} \mathrm{DNA}$ synthesis and doubling of the genome take place during the synthetic or $S$ phase. This is preceded by a period of variable duration known as the first gap $\left(G_{1}\right)$ phase which separates the $S$ phase from the previous mitosis
(M phase). The $\mathrm{S}$ phase is followed by a period of apparent inactivity known as the second gap phase $\left(G_{2}\right)$ which comes before the next mitosis. Interphase comprises successive $G_{1}, S$, and $G_{2}$ phases and forms the largest part of the cell cycle. Lajtha proposed that there is a further phase in the cell cycle $\left(\mathrm{G}_{0}\right)$ in which cells are not part of the cell cycle but, after suitable stimuli, may rejoin the cycling population. ${ }^{6}$ Not all authors, however, are agreed on the nature of $G_{0}$. In any tissue there are also cells that, for whatever reason, can no longer divide and so any cell population can be divided into a cycling and a non-cycling compartment. This naturally leads to the definition of the proliferative or growth fraction of any cellular population as the ratio of cycling to cycling plus non-cycling cells. ${ }^{7}$

Although there is a great deal which remains unclear, large advances have been made in our understanding of the regulation of the eukaryotic cell cycle. At a simple phenomenological level molecules can be identified, especially proteins, whose functional state varies in synchrony with the cell cycle, either in protein level or in activity. ${ }^{89}$ In model systems such as yeast, cell cycle mutants can be identified by conventional and molecular genetic analyses, and these approaches have led to the cloning and sequencing of genes involved in the cell cycle. Biochemical methods have also been used to define enzymatic activities involved in various phases of the cell cycle, such as in DNA
Histopathology Unit Imperial Cancer Research Fund, Lincoln's Inn Fields, London P A Hall

Department of Histopathology UMDS, Guy's Hospital, London D A Levison

Correspondence to: P A Hall, Histopathology Unit, Imperial Cancer Research Fund, Lincoln' Inn Fields, PO Box 12 6 September 1989
CYCLING

NON-CYCLING

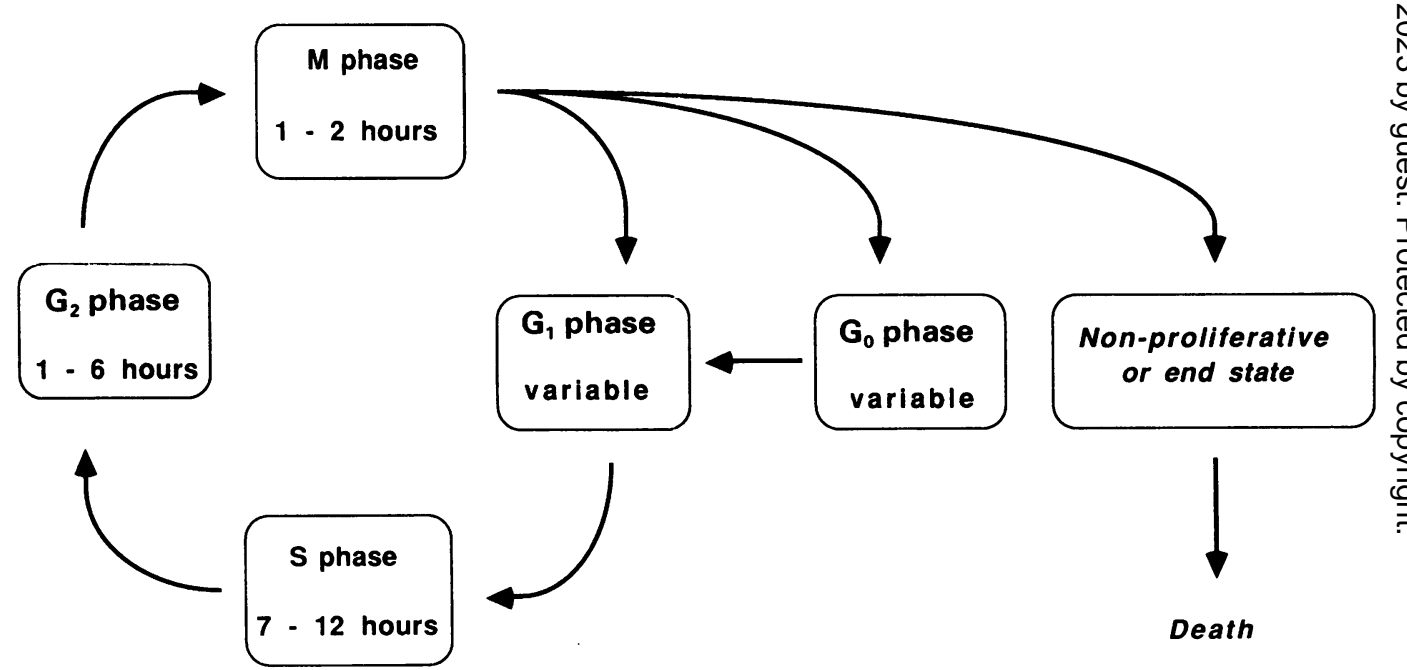

Figure The cell cycle, adapted from Wright. ${ }^{3}$ It should be remembered that there may be considerable variation in the duration of phases of the cell cycle within and between tissues, both normal and neoplastic. ${ }^{3 *}$. 
synthesis. The results of such strategies indicate that the molecular control of cellular proliferation has been remarkably conserved through evolution with similar regulatory mechanisms operating in all eukaryotes, with cascades of regulatory genes which seem to have a role in controlling cell division. ${ }^{910}$ For example, a key gene in yeast and in man encodes a 34 kilodalton protein kinase, essential for cell division, known as $c d c 2 .{ }^{11-13}$ The level of this protein does not change during the cell cycle but its functional activity does as a consequence of altered phosphorylation ${ }^{14}{ }^{15}$; phosphorylation of target proteins, which changes their function, is a particularly prevalent regulatory mechanism in cell cycle control.

Other important cellular proteins involved directly or indirectly in the control of cell proliferation have been identified. For example, cyclins are a group of proteins (also known as proliferating cell nuclear antigens or PCNA), which accumulate progressively through interphase and disappear at the end of mitosis. These proteins are now known to be components of DNA polymerase $\delta$ and are essential for completion of the cell cycle. ${ }^{91617}$ These occur throughout eukaryotes, including plants. ${ }^{18}$ Several histone proteins vary in synchrony with the cell cycle and could be suitable markers for assessing changes associated with cell proliferation. ${ }^{19}$ The regulation of genes related to the cell cycle by specific promoter sequences is also now becoming better understood..$^{20}$ Finally, there seem to be specific genes associated with growth arrest in mammalin cells, although these are as yet only poorly characterised. ${ }^{21} 22$

There seem to be numerous functionally interrelated substances that vary in level or activity during the cell cycle, whose functions (whether structural or regulatory) are to permit the initiation and completion of normal cell division. Against this background a variety of cellular changes can be identified which can be used to pinpoint cell proliferation in histological material. In simple terms, mitoses can be counted, the incorporation of nucleotides (or their analogues) into newly synthesised DNA during the $S$ phase can be identified, and the varying levels of structural or functional moieties associated with different aspects of the cell cycle can be assayed. Antibodies have been raised to the products of several cell division cycle (cdc) genes in yeast and can detect the relevant protein in both biochemical assays and immunohistochemical preparations. ${ }^{1023}$ Antibodies have been used to show the presence of cyclin/PCNA and other gene products related to the cell cycle such as DNA polymerase $\alpha$. Many other cell cycle related proteins will also probably be useful in the histological assessment of cell proliferation or exit from the proliferative compartment.

\section{Methods for assessing cellular proliferation \\ MITOSES}

The mitotic phase of the cell cycle is the only part that can be recognised by simple morphological examination, and the reader is referred to standard texts for the classic morphological features of the mitotic cycle. ${ }^{1}$ As these features are so well described the assessment of cell proliferation by counting mitoses should be straightforward; this method is considered to provide useful information in many tumours such as lymphomas, ${ }^{24}{ }^{25}$ melanomas, ${ }^{26}$ soft tissue sarcomas, ${ }^{27}$ especially smooth muscle tumours. ${ }^{28}$ It is part of the grading system of several tumours, notably carcinoma of the breast.

Several potential problems must be considered in the use of mitoses as an indicator of proliferation. The identification of mitoses can be very difficult; careful microscopical examination is essential, only those cells that are unequivocally in mitosis are acceptable for counting. Pyknotic nuclei and suspicious cells should be excluded. ${ }^{28-30}$ When the number of mitoses per high power field is counted, the area of the high power field should be given; ${ }^{31}$ preferably the number of mitoses per 1000 cells should be stated. The process of mitosis in inadequately fixed material may go on to completion, while few if any new mitoses will be initiated, leading to a considerable underestimate of the true numbers of mitoses and apparent regional variations. ${ }^{32} 33$

\section{DNA CONTENT}

Another approach to assessing cell proliferation is to take advantage of the process of DNA synthesis. A normal somatic cell has a diploid genome; DNA synthesis during $S$ phase leads to a doubling of the genetic information and the cell becomes temporarily tetraploid. This process can be measured in several ways.

\section{Thymidine labelling}

The introduction of tritiated thymidine and the development of high resolution autoradiography during the 1950 s led to the use of thymidine labelling as the "gold standard" for cell kinetic studies. The method requires viable cells to take up tritiated thymidine and for this to be incorporated into DNA during the $S$ phase. It consequently requires the in vivo administration of radiolabelled thymidine which can rarely be justified in clinical practice. Alternatively, biopsy and other specimens must be incubated with tritiated thymidine for some time in vitro before fixation. Both of these restraints militate against thymidine labelling as a practical routine procedure for histopathologists. In some centres, however, thymidine labelling has been extensively used on clinical material from a wide range of conditions, ${ }^{34-36}$ particularly lymphomas ${ }^{37-39}$ and breast carcinoma. ${ }^{40}$ Several authors have reported that thymidine labelling provides information of prognostic relevance in non-Hodgkin's lymphomas $^{41-43}$ and the demonstration of incorporation of tritiated thymidine by scintillation counting seems to provide similar information. ${ }^{45}$ Studies of breast carcinoma indicate that thymidine labelling indices closely correlate with several pathological and clinical variables and that it is a predictor of 
biological behaviour. ${ }^{4046} 47$. In other tumours the clinical importance of thymidine labelling indices has been less clear cut. ${ }^{48}$

\section{Bromodeoxyuridine incorporation}

Synthesis of DNA can also be assessed by measuring the incorporation of a thymidine analogue such as bromodeoxyuridine. This molecule can then be detected by specific antibodies, ${ }^{49} 50$ either in tissue sections or by flow cytometry, ${ }^{5051}$ and used for detailed cell cycle analysis ${ }^{52}$ as with thymidine incorporation. The disadvantages are similar to those of tritiated thymidine, in particular the need for in vivo administration or in vitro incubation. Ethical permission for some in vivo studies has been obtained, however, and in vitro incubation of biopsy or other surgical specimens is feasible..$^{53-55}$.

\section{Flow cytometry}

The capacity of some dyes to bind to DNA in a stoichiometric manner means that the amount of DNA present in a nucleus can be determined, at least in comparison with some reference standard. The method of static cytometry has been widely used to investigate the relative DNA content of cells, but only relatively limited information can be obtained and that relates to ploidy rather than proliferation itself. Considerably more information can be obtained using flow cytometry in which large numbers of cells are analysed and appropriate statistical methods applied to the resulting data to give information about DNA content and cell cycle variables.

The principles of flow cytometry have been reviewed elsewhere. ${ }^{5657}$ In brief the procedure involves the examination of a single cell suspension passing a given point, by a suitably tuned laser beam, with reflected or transmitted light, or both, being detected by suitably placed detectors and converted into an electronic signal. Many variables can be assessed-for example, the presence on the cell of a fluorescent dye linked to an antibody, or the fluorescence due to a dye bound to nucleic acid. Information about the number of cells and their DNA content can be obtained from these data, providing kinetic information if suitably analysed. ${ }^{58}$ In the absence of aneuploidy cells in $G_{0}, G_{1}$ will be diploid, cells in $G_{2}$ will be tetraploid, and cells in $S$ phase will have intermediate amounts of DNA. Assessment of kinetic variables is considerably complicated by the presence of aneuploidy, ${ }^{59}$ but with suitable mathematical analysis, the $S$ phase fraction can be determined in most such cases..$^{6061}$

Of particular interest is the fact that DNA content can be measured in nuclei recovered from fixed and paraffin wax embedded histopathological material. ${ }^{6263}$ Many different pathological conditions have been studied with this technique, but as with other methods of assessing cell proliferation, much attention has been given to lymphoid neoplasms including Hodgkin's disease ${ }^{64}$ and non-Hodgkin's lymphomas ${ }^{65-68}$. Flow cytometry has also been applied to cytological preparations. ${ }^{69}$ Some studies have shown that flow cytometric assessment of proliferative indices has prognostic value $^{70-74}$ and can predict the response to treatment, particularly in high grade tumours ${ }^{75-77}$; it may also be useful within histological categories such as centroblastic-centrocytic lymphoma. ${ }^{78}$ Flow cytometric studies of breast carcinoma have been reported ${ }^{79-82}$ and some have indicated that this method of assessing cell proliferation provides prognostic information, ${ }^{83-85}$ although this is, predictably, correlated closely with histological tumour grade. Studies of other tumours such as colorectal cancer, ${ }^{86}$ gastric cancer and precancer, ${ }^{87}$ lung tumours, ${ }^{88}$ and melanoma ${ }^{89}$ have been reported.

The most important disadvantages of flow cytometry include the cost of the equipment required, the need to disrupt tissues so that the spatial relation of cellular subpopulations is lost, and the possible inclusion of admixed nonneoplastic cells in samples. On the other hand, the information obtained is objective and represents measurements on very large numbers of cells, in contrast to most of the other methods described for the investigation of cell proliferation.

\section{IMMUNOHISTOCHEMICAL METHODS}

As well as their use in the immunohistochemical demonstration of bromodeoxyuridine, antibodies have become an important means of assessing cell proliferation. A particular advantage is that the immunohistological demonstration of cell cycle related antigens allows spatial orientation to be shown, and the phenotype of proliferating cells can be determined by double staining methods. $\mathrm{C}_{5} \mathrm{~F}_{10}$, an antibody, which recognises cells in mitosis has been described ${ }^{90}$ but this has been found to cross-react with many other cellular components and offers few advantages over conventional assessment of mitoses in histological sections (P A Hall, unpublished observations).

Perhaps the best known antibody that recognises proliferating cells is Ki67. This identifies a poorly characterised nuclear antigen associated with the cell cycle, being expressed in all phases except $\mathrm{G}_{0}{ }^{91}{ }^{92}$ Recent studies using a variety of techniques, including confocal microscopy, suggest that the antigen is a component of the nuclear matrix..$^{9394}$ Several studies have shown that there is a close correlation between $\mathrm{Ki} 67$ immunoreactivity and other variables of cellular proliferation such as thymidine labelling, ${ }^{95-98}$ bromodeoxyuridine incorporation, ${ }^{969-102}$ and flow cytometry. ${ }^{95103104}$ There is evidence, however, that in nutritionally deprived cells (which are not uncommon in tumours) there can be a discrepancy between $\mathrm{Ki} 67$ immunoreactivity and other variables of cellular proliferation..$^{94} 105106$ Nevertheless, Ki67 immunostaining has been extensively used as an operational marker of cellular proliferation and, although certain caveats have been raised, will probably remain a popular method. A major limitation to its use, however, has been the need for fresh or snap frozen material as the antigen is very sensitive to fixatives and may deteriorate with time even when stored at $-20^{\circ} . .^{107}$ 
Ki67 immunostaining has been used in numerous disease states including tumours such as non-Hodgkin's lymphomas, ${ }^{100} 108109$ Hodgkin's disease, ${ }^{110111}$ plasma cell tumours, ${ }^{112}$ breast cancer ${ }^{113-115}$ soft tissue tumours, ${ }^{116}$ brain tumours, ${ }^{117118}$ lung, ${ }^{119}$ cervical $^{120}$ and colorec$\mathrm{tal}^{121}$ carcinomas and liver tumours. ${ }^{122} \mathrm{Ki} 67$ immunoreactivity seems to provide prognostically useful information in lymphoma, ${ }^{100109123124}$ and this may also be the case in breast cancer. ${ }^{125}$ As with other clinicopathological studies of cell proliferation, differences in quantitation, presentation of the results, and most importantly, the way in which the patients were treated make direct comparisons of these studies difficult. Ki67 immunostaining has also been applied to non-neoplastic conditions including reactive lymphoid lesions, ${ }^{126} 127$ renal biopsy specimens from transplant patients and cases of glomerulonephritis, ${ }^{128}$ inflammatory bowel disease, ${ }^{129}$ biopsy specimens of synovia in degenerative joint disease, ${ }^{130}$ endometrial stroma, ${ }^{131}$ and sarcoidosis, ${ }^{132}$ and in both histological and cytological material. ${ }^{11133134}$

Another approach has been to use antibodies that recognise some component of the cellular DNA replication machinery such as DNA polymerase $\alpha$, which is transcriptionally regulated in a cell cycle dependent manner. ${ }^{135}$ This enzyme can be recognised in cytological and histological material by monoclonal antibodies, ${ }^{136137}$ and these have been successfully applied to a variety of clinical specimens, including lymphomas. ${ }^{138139}$ Other authors have proposed that the immunohistological demonstration of transferrin receptor (CD71) can be used as an index of cellular proliferation and can provide useful clinical information, at least in non-Hodgkin's lymphoma. ${ }^{140}$ The transferrin receptor is expressed widely, not only on proliferating tissues but also on those that are non-proliferating but metabolically active, ${ }^{141}$ and is thus a poor index of cellular proliferation. ${ }^{142}$

Autoantibodies which react with nuclear antigens in proliferating cells are found in some patients with connective tissue diseases, and the possibility that they may be useful biological markers for the study of proliferating cells has been recognised for some time. ${ }^{143144}$ One particular group of autoantibodies recognises cyclin/PCNA. ${ }^{145}$ Human antibodies, or murine monoclonal antibodies which recognise cyclin/PCNA, have been used in cytological ${ }^{146}$ and histological material and have recently been reported to provide a simple method of recognising proliferating cells in methacarn or alcohol fixed, wax embedded tissue, with results comparable with those achieved with flow cytometry. ${ }^{147}$ Other nuclear antigens have been reported whose expression is temporarily related to cellular proliferation, and some are localised in the nucleolus. It seems very likely that antibodies which recognise other structural or functional molecules regulated during the cell cycle will become available.

NUCLEOLAR ORGANISER REGIONS

Nucleolar organiser regions represent loops of
DNA which have the genes for ribosomal RNA, together with associated proteins, ${ }^{148}$ although the function of these nucleic acidprotein complexes is not fully understood. The proteins shown by the argyrophilic method are possibly related to RNA polymerase $\mathrm{I}^{149}$ or other proteins such as $\mathrm{C}_{23}$ (nucleolin) ${ }^{150-152}$ and $\mathrm{B}_{23}$ protein. ${ }^{152}$ The exact function of these proteins remains uncertain but they may maintain DNA in an extended configuration ${ }^{153}$ or have some regulatory function in controlling the transcription of the genes for ribosomal RNA. ${ }^{154-156}$

The assessment of silver stained nucleolar organiser regions (AgNORs) in histopathological material has been popularised by Crocker, ${ }^{148157}$ who has applied methods that had been used extensively in cytogenetics for many years. Simple silver staining methods can be used to show the presence of proteins associated with nucleolar organiser regions in interphase chromosomes in conventional histological sections, and these can be counted. ${ }^{158}$ As nucleolar organiser regions are associated with acrocentric chromosomes it was initially thought that these data would largely reflect ploidy, but correlation with conventional histological variables, ${ }^{148}$ with $\mathrm{Ki} 67$ immunoreactivity, ${ }^{159}$ and with flow cytometry ${ }^{160}$ suggested that AgNORs are more closely related to cell proliferation than to ploidy. Recent studies of interphase nuclei with morphological, ${ }^{161}$ cytogenetic, ${ }^{162}$ and cell kinetic ${ }^{163}$ methods suggest that the number of interphase nucleolar organiser regions is strictly correlated with cell proliferation.

Recently there have been many studies describing the application of silver staining methods for the demonstration of AgNORs in histological material from a wide range of diseases. ${ }^{148}$ Assessment of AgNORs seems to give similar information as other indices of cellular proliferation in lymphomas (Hall PA, Crocker J, Murray BG, Levison DA, unpublished observations)..$^{157} 159$ Nucleolar organiser region staining is claimed to be of diagnostic value in numerous conditions including childhood tumours, ${ }^{164}$ soft tissue tumours, ${ }^{148}$ melanocytic and other cutaneous lesions, ${ }^{165}$ and tumours of breast, ${ }^{166}$ lung, ${ }^{167}$ salivary gland, ${ }^{168}$ cervix, ${ }^{169}$ central nervous system, liver, and gastrointestinal tract. ${ }^{148}{ }^{170}$ Nucleolar organiser regions can also be shown in cytological preparations and AgNOR staining can be combined with immunohistochemistry. ${ }^{164171}$

In some tissues such as thyroid ${ }^{172}$ nucleolar organiser regions are reported to be less useful and some studies suggest that the counting of AgNORs may not provide pathologists with additional information. ${ }^{173174}$ With the exception of preliminary reports on neuroblastoma and other childhood tumours, ${ }^{175}$ little information on the prognostic importance of AgNOR staining is available. The present evidence suggests that nucleolar organiser regions represent a means of assessing cellular proliferation, but a better understanding of nucleolar organiser regions and their component proteins is vital for the rational interpretation of this method. Further studies are needed 
to substantiate early claims that assessment of nucleolar organiser regions may be useful in histopathological diagnosis.

\section{Quantitation}

Irrespective of the method used for the assessment of cell proliferation, it is important to consider how it should be quantitated. Flow cytometry analyses very large numbers of cells, but considerably fewer are generally examined in the other methods. For the immunohistochemical assessment of proliferation, some authors have used manual counting of cells on tissue sections, and this may be very time consuming as many cells must be counted. ${ }^{109113121}$ There is no absolute answer to the question, how many cells need to be counted? In fact, the more pertinent question is how many cells need to be counted to be able to distinguish confidently between two values? This topic is well reviewed elsewhere. ${ }^{176-178}$ An alternative is to use a semiquantitative method and this seems to give reproducible results. ${ }^{119121178}$ Image analysis techniques have also been successfully applied to sections and fine needle aspirates immunostained with Ki67. ${ }^{115} 179180$

Heterogeneity within a specimen must also be considered, particularly in tumours: $:^{35113121181182}$ there are functionally and kinetically distinct populations in normal and pathological tissues. ${ }^{36182183}$ For example, there is good evidence that stem cells are present in tumours and these may represent the predominant biologically and therapeutically relevant population. ${ }^{354-186}$ Consequently the assessment of cell proliferation in different subpopulations may provide more meaningful information than crude assays that use all the cells in the sample as the denominator when deriving proliferation indices. In situ methods such as immunohistochemcial techniques combined with double staining methods for phenotypic markers may provide new approaches to the functional analysis of the proliferative characteristics of tissues, particularly neoplasms. Heterogeneity may extend to there being different kinetic indices in tumour samples from different sites, ${ }^{187}$ and this and other aspects of kinetic heterogeneity may have considerable therapeutic implications. ${ }^{188}$

\section{"Rates not states"}

The methods for assessing cellular proliferation so far described provide information about the proportion of cells cycling at any given moment-that is, the state of proliferation. Such measurements provide no information about the rate of proliferation which requires measurement of (i) the rate at which cells enter the cycle and (ii) how long they remain there. The importance of the distinction between rates and states of proliferation is illustrated by a simple example. If the length of time spent in the cell cycle is long, then many cells will appear to be in cycle at any given moment, although the population may be proliferating quite slowly. Consequently information about proliferative rates can be more informative than proliferative states. Such information is, in general, more difficult to obtain.

Several methods can be used to obtain information about proliferative rates. ${ }^{3536177}$ These include metaphase arrest or stathmokinetic methods to determine the rate of mitosis, or labelling methods using pulses of thymidine and multiple biopsy specimens, double labelling or continuous labelling methods, and the fraction of labelled mitosis technique. These complex and time consuming methods are rarely practical in clinical material due to the need for the in vivo administration of toxic substances or the need for in vitro incubations. They also require multiple biopsy specimens in most cases. Thornton, however, has recently reported the application of a double labelling method, with both thymidine and bromodeoxyuridine incorporation, for the measurement of the $S$ phase duration in endometrial biopsy specimens, ${ }^{189}$ and other studies of clinical material have been reported. Differences within and between tumours in the duration of the cell cycle may also be of clinical importance, yet are not shown by simple "state" measurements. ${ }^{35}$ Cell loss is also an important component of the kinetic state of tissue, including tumours, but this is difficult to quantify. ${ }^{35190}$ The assessment of numbers of apoptotic bodies provides an index of the state of cell death, but information on rate of cell death is more difficult to obtain. ${ }^{191}$ Loss of cells from the proliferative compartment-for example, by differentiation-is also difficult to assess.

\section{Conclusions and prospects}

The assessment of cellular proliferation in histological material is a valuable component of conventional histopathological analysis, and a variety of methods can be used to quantify this. Ideally such methods should be simple, reproducible, and applicable to conventionally processed histological and cytological preparations. The method should be relatively inexpensive and interpretation of the results should be straightforward. Many of the different methods described in this review measure slightly different variables, and although comparable, the data produced are not identical. It is always useful to consider the nature of the biological process being used as an index of proliferation. With mitoses, the $S$ phase fraction, and other markers of DNA synthesis this is quite simple, but with AgNORs and Ki67 immunostaining, we remain uncertain as to exactly what is being measured. At present the available methods all have some disadvantages.

It should be remembered that cell proliferation is a normal biological process. Many normal tissues are actively proliferating-for example, germinal centres and colonic and small intestinal crypt epithelium. As a consequence the interpretation of indices of cell proliferation should always be in the context of knowledge of the proliferative nature of the normal tissue. Such an argument leads to the inevitable conclusion that methods which permit in situ assessment of cellular proliferation, such as mitosis counting or immunohisto- 
chemical methods, may be preferable to those methods that require the disruption of tissues such as flow cytometry. The identification and cloning of genes and their products which regulate the cell cycle may lead to the analysis of cell proliferation in histological material by the use of peptide specific antibodies directed at these molecules.

Assessment of cell proliferation has numerous applications. Many are already well defined, as in the counting of mitoses in smooth muscle tumours. There is considerable evidence that assessing cellular proliferation in a variety of tumours provides useful information and may be of major prognostic importance. Further studies along these lines with careful clinicopathological correlation are needed to confirm such ideas, but multivariate analyses are urgently required to establish that cell proliferation provides information independent of other clinical and histological variables. For example, O'Rielly et al have shown that $S$-phase fraction determined by flow cytometry is of prognostic importance in breast cancer, but that in a multivariate analysis histological grade and S-phase fraction seemingly provide equivalent information. ${ }^{85}$ Moreover, despite the numerous studies reporting the assessment of cell proliferation in tumours, it does not yet directly influence patient management, with the possible exception of smooth muscle tumours. The analysis of cell cycle times and correlation with clinical variables are needed, and the possibility that assessment of cellular proliferation during and after treatment may give clinically useful information about response should be considered. Given the extensive phenotypic and kinetic heterogeneity seen in tumours, studies to define proliferative capacity in phenotypically defined subpopulations, such as those containing stem cells, may provide information of more biological and clinical relevance than simple measures of proliferation. Finally, the application of these methods to non-neoplastic conditions-for example, in the study of glomerulonephritis and transplant rejection in renal biopsy specimens-are areas that should be explored.

We thank Professor Nick Wright and Drs Mike Richards, Robin Dover, John Crocker and David Lowe for their comments on the manuscript. We are grateful to Susan Brooks and Drs Tony Leathem, Kevin Gatter, David Brown and Susan O'Rielly for allowing us access to unpublished data and Richard Camplejohn for useful discussion.

1 Alberts B, Bray D, Lewis J, Raff M, Robert K, Watson JD Molecular biology of the cell. 2nd ed. New York: Garland Publishing Inc. 1989

2 Leblond CP. Classification of cell populations on the basis of their proliferative behaviour. NCI Monogr 1963;14:19-145.

3 Wright NA. Cell proliferation in health and disease. In: Anthony PP, MacSween RM, eds. Recent advances in histopathology. Volume 12, Edinburgh: Churchill Livingstone, 1984:17-33.

4 Howard A, Pelc SR. Nuclear incorporation of ${ }^{32} \mathrm{P}$ as 2:178-87.
5 Howard A, Pelc SR. Synthesis of desoxyribonucleic acid in normal and irradiated cells and its relation to chromosome breakage. Heredity 1953;(Suppl 6):173-261.

6 Lajtha LG. On the concept of the cell cycle. J Cell Comp Physiol 1963;62(Suppl 1):143-5.

7 Mendelsohn ML. The growth fraction: A new concep applied to tumours. Science 1963;132:1496.

8 Kaczmarek L. Protooncogne expression during the cell cycle. Lab Invest 1986;54:365-76.

9 Dunphy WG, Newport JW. Unravelling of mitotic control mechanisms. Cell 1988;55:925-8.

10 Lee $M$, Nurse $P$. Cell cycle control genes in fission yeast and mammalian cells. Trends in Genetics 1988:4:287-90.

11 Lee MG, Nurse P. Complementation used to clone a human homologue of the fission yeast cell cycle gene cdc2. Nature 1987;327:31-5.

12 Draetta G, Brizuela L, Potashkin J, Beach D. Identification of p34 and p13, human homologs of the cell cycle regulators of fission yeast encoded by cdc2 + and sucl + Cell 1987;50:319-25.

13 Riabowol K, Draetta G, Brizuela L, Vandre D, Beach D. The cdc 2 kinase is a nuclear protein that is essential for mitosis in mammalian cells. Cell 1989;57:393-401.

14 Draetta $G$, Beach D. Activation of cdc2 protein kinase during mitosis in human cells: cell cycle-dependent phospohorylation and subunit rearrangement. Cell phospohorylation

15 Draetta G, Piwnica-Worms H, Morrison D, Druker B, Roberts T, Beach D. Human $c d c 2$ protein kinase is a mahor cell-cycle regulated tyrosien kinase substrate Nature 1988;326:738-44.

16 Bravo R, Frank R, Blundell PA, Macdonald-Bravo $H$. Cyclin/PCNA is the auxilliary protein of DNA polymerase $x$. Nature 1987;326:515-17.

17 Prelich G, Tan C-K, Kostura M, et al. Functional identity of proliferating cell nuclear antigen and DNA polymerase $x$ auxilliary protein. Nature 1987;326:517-20.

18 Suzuka I, Daidoji $H$, Matsuoka M, et al. Gene for proliferating-cell nuclear antigen (DNA polymerase $\alpha$ auxilliary protein) is present in both mammalian and higher plant genomes. Proc Natl Acad Sci USA 1989; 86:3189-93.

19 Schumperli D. Cell-cycle regulation of histone gene expression. Cell 1986;45:471-2.

20 Breeden L. Cell-cycle regulated promoters in budding yeast. Trends in Genetics 1988;4:249-53.

21 Schneider C, King RM, Philipson L. Genes specifically expressed at growth arrest of mammalian cells. Cell 1988;54:787-93.

22 Wang E. Rapid disappearance of statin, a non-proliferating and senescent cell-specific protein, upon reentering the process of cell cycling. J Cell Biol 1985;101:1695-701.

23 Simanis V, Nurse $P$. Characterisation of the fission yeast cdcl0 + protein that is required for commitment to the cell cycle. J Cell Sci 1989;92:51-6.

24 Akerman M, Brandt L, Johnson A, Olson H. Mitotic activity in non-Hodgkin's lymphoma. Relation to the Kiel classification and to prognosis. Br J Cancer 1987; 55:219-23.

25 Ellison DJ, Nathwani BN, Metter GE, et al. Mitotic counts in follicular lymphomas. Hum Pathol 1987;18:502-5.

26 Ronan SG, Das Gupta TK. Histologic prognostic indicators in cutaneous malignant melanoma. Semin indicators in cutaneous
Oncol 1988;15:558-65.

27 Tsujimoto M, Aozasa K, Ueda T, Morimura Y, Komatsubara Y, Doi T. Multivariate analysis for histologic prognostic factors in soft tissue sarcomas. Cancer 1988;62:994-8.

28 Silverberg SG. Reproducibility of the mitosis count in the histologic diagnosis of smooth muscle tumours of the uterus. Hum Pathol 1976;7:451-4.

29 Scully RE, Kempson RL, Norris HL. Mitosis counting. Hum Pathol 1976;7:481-4.

30 Donhuijesen K. Mitosis counts: reproducibility and significance in grading of malignancy. Hum Pathol

31 Ellis PSJ, Whitehead R. Mitosis counting-A need for reappraisal. Hum Pathol 1981;12:3-4.

32 Evans N. Mitotic figures in malignant tumours as affected by time before fixation of tissues. Arch Pathol 1926;1 894-8

33 Graem N, Helweg-Larsen K. Mitotic activity and delay in fixation of tumour tissue. Acta Path Microbiol Scand A $1979 ; 87: 375-8$

34 Malaise EP, Chavaudra N, Tubiana $M$. The relationship between growth rate, labelling index and histological type of human solid tumours. Eur $J$ Cancer 1973;9: type of

35 Steel GG. Growth kinetics of tumours. Oxford: Clarendon Press, 1977.

36 Wright NA, Alison M. The biology of epithelial cell populations. Oxford: Clarendon Press, 1984

37 Cooper EH, Peckham MJ, Millard RE, Hamlin IME Gerard-Marchant $R$. Cell proliferation in human malig nant lymphomas. Analysis of labelling index and DNA content in cell populations obtained by biopsy. Eur Cancer 1976;4:287-96.

38 Peckham MJ, Cooper EH. Proliferation characteristics of the various classes of cells in Hodgkin's disease. Cancer 1969;24:135-46.

39 Peckham MJ, Cooper EH. The pattern of cell growth in reticulum cell sarcoma and lymphosarcoma. Eur J Cancer 1970;6:453-63.

40 Meyer JS, Prey MU, Babcock DS, McDivitt RW. Breas carcinoma cell kinetics, morphology, stage and host 
characteristics. A thymidine labelling study. Lab Invest 1986;54:41-51.

41 Costa A, Bonadonna G, Villa E, Valagussa P, Silverstrini R. Labelling index as a prognostic marker in non-Hodgkin's lymphoma. JNCI 1981;66:1-5.

42 Silvestrini R, Piazza R, Riccardi A, Rilke F. Correlation of kinetic findings with morphology of non-Hodgkin's lymphomas. JNCI 1977;58:499-504

43 Brandt L, Olsson H, Monti M. Uptake of thymidine in lymphoma cells obtained through fine-needle aspiration biopsy. Relation to prognosis in non-Hodgkin's lymbiopsy. Relation to prognosis in non-

44 Kvaloy S, Godal T, Marton PF, Steen H, Brennhovd IO Abrahamsen AF. Spontaneous $\left({ }^{3} \mathrm{H}\right)$-thymidine uptake b histological subgroups of human B cell lymphomas. Scan J Haematol 1981;26:221-34

45 Kvaloy S, Morton PF, Kaalhus O, Hoie J, Foss-Abrahamsen A, Godal T. $3 \mathrm{H}$ thymidine uptake in B cell lymphomas. Relationship to treatment response and survival. Scand J Haematol 1985;34:429-35.

46 Meyer JS, Friedman E, McCrate MM, Bauer WC. Prediction of early course in breast carcinoma by thymidine labelling. Cancer 1983;51:1879-86.

47 Gentili C, Sanfilippo O, Silvestrini R. Cell proliferation and its relationship to clinical features and relapse in breast cancers. Cancer 1981;48:974-9.

48 Kerr KM, Lamb D. A comparison of patient survival and tumour growth kinetics in human bronchogenmic carcinoma. Br J Cancer 1988;58:419-22.

49 Gratzner HG. Monoclonal antibody to 5-bromo and 5iodo-deoxyuridine: a new reagent for detection of DNA replication. Science 1982;218:474-5.

50 Gray JW, Mayal BH. Monoclonal antibodies against bromodeoxyuridine. New York: Alan R Liss Inc, 1985

51 Dolbeare F, Gratzner H, Pallavicini MG, Gray JW. Flow cytometric measurement of total DNA content and incorporated bromodeoxyuridine. Proc Natl Acad Sci USA 1983;80:5573-7.

52 Dean PN, Dolbeare F, Gratzner H, Ricve GC, Gray JW. Cell-cycle analysis using a monoclonal antibody to BrdUrd. Cell Tiss Kinet 1984;17:427-36.

53 Wilson GD, McNally NJ, Dische S, et al. Measurement of cell kinetics in human tumours in vivo using bromodeoxyuridine incorporation and flow cytometry. Br J Cancer 1988;58:423-31.

54 Riccardi A, Danova M, Dionigi P, et al. Cell kinetics in leukaemia and solid tumours studied with in vivo bromodeoxyuridine and flow cytometry. Br J Cancer 1989;59:898-903.

55 Thornton JG, Wells $M$, Hume WJ. Flash labelling of S phase cells in short term organ culture of normal and pathological human endometrium using bromodeoxyuridine and triated thymidine. J Pathol 1988;154:321-8.

56 Shapiro HM. Practical flow cytometry. 2nd Ed. New York: Alan R Liss, 1988

57 Quirke P, Dyson JED. Flow cytometry: methodology and applications in pathology. $J$ Pathol 1986;149:79-87.

58 Baisch H, Beck HP, Christensen IJ, et al. A comparison of mathematical methods for the analysis of DNA histograms obtained by flow cytometry. Cell Tiss Kin 1982;15: 235-49.

59 Friedlander ML, Hedley DW, Taylor IW. Clinical and biological significance of aneuploidy in human tumours. $J$ Clin Pathol 1984;37:961-74.

60 Masters JRW, Camplejohn RS, Millis RR, Rubens RD. Histological grade, elastosis, DNA ploidy and response to chemotherapy of breast cancer. Br J Cancer 1987;50: 455-7.

61 Camplejohn RS, Macartney JC, Morris RW. S phase fraction in lymphoid tissue: fresh versus paraffin embedded tissue and DAPI versus PI staining. Cytometry 1989;10:410-6.

62 Hedley DW, Friedlander ML, Taylor IW, Rugg CA, Musgrove EA. Method for analysis of cellular DNA content of paraffin embedded pathological material using flow cytometry. J Histochem Cytochem 1983;31:1333-5.

63 Hedley DW, Friedlander ML, Taylor IW. Application of DNA flow cytometry to paraffin embedded archival
material for the study of aneuploidy and its clinical significance. Cytometry 1985;6:26-30.

64 Morgan KG, Quirke P, O'Brien CJ, Bird CC. Hodgkin's disease: a flow cytometric study. J Clin Patho $1988 ; 41: 365-9$.

65 Braylan RC, Diamond LW, Powell ML, Harty-Golder B Percentage of cells in the S-phase of the cell cycle in human lymphoma determined by flow cytometry. Correlation with labelling index and patient survival. Cytometry 1980;1:171-4.

66 Diamond LW, Nathwani BN, Rappaport H. Flow cytometry in the diagnosis and classification of malignan lymphoma and leukaemia. Cancer 1982;50:1122-5.

67 Juneja SK, Cooper IA, Hodgson GS, et al. DNA ploidy patterns and cytokinetics of non-Hodgkin's lymphoma. Clin Pathol 1988;39:987-92.

68 Egerter DA, Said JW, Epling S, Lee S. DNA content of T cell lymphomas. A flow cytometric analysis. Am J Patho $1988 ; 130: 326-34$

69 Joensuu H, Klemi PJ, Eerola E. Diagnostic value of DNA flow cytometry combined with fine needle aspir

bous

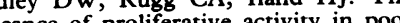
prognostic signifance or prolise histology non-Hodgkin's lymphoma: a fancer Clin Oncol study using archiva
71 Joensuu H, KLemi PJ, Korkeila E. Prognostic value of DNA ploidy and proliferative activity in Hodgkin's disease. Am J Clin Pathol 1988;90:670-3.

22 Mor DR, Williamson JMS, Quirke P, et al. DNA Content and prognosis in non-Hodgkin's lymphoma. $\mathrm{Br} J$ Cancer 1986;54:643-9.

73 Roos G, Dige U, Lenner P, Lindh J, Johansson $H$. Prognostic significance of DNA analysis by flow cytometry in no

74 Lehtinen $\mathrm{T}$, Aine R, Lehtinene $\mathrm{M}$, et al. Flow cytometric DNA analysis of 199 histologically favourable or unfavourable non-Hodgkin's lymphomas. J Pathol 1989;157:27-36.

75 Srigley J, Barlogie B, Butler JJ, et al. Heterogeneity of nonHodgkin's lymphoma probed by nucleic acid cytometry. Blood 1985;65:1090-6.

76 Bauer KD, Merkel DE, Winter JN, et al. Prognostic implications of ploidy and proliferative activity in diffuse large cell lymphoma. Cancer Res 1986;46:3173-8.

77 O'Brien CJ, Holgate C, Quirke P, et al. Correlation of morphology, immunophenotype and flow cytometry with Hodgkin's lymphoma. J Pathol 1989;158:31-9.

78 Griffin NR, Howard MR, Quirke P, O'Brien CJ, Childs Griffin NR, Howard MR, Quirke P, O'Brien CJ, Childs JA, Bird CC. Prognostic indicators in centroblast

79 Walker RA, Camplejohn RS. DNA flow cytometry of human breast carcinomas and its relationship to transferrin and epidermal growth factor receptors. J Patho 1986;150:37-42.

80 Olszewski W, Darzynkiewicz Z, Rosen PP, Schwartz MK Melamed MR. Flow cytometry of breast carcinoma: II Relation of tumour cell cycle distribution to histology and estrogen receptor. Cancer 1981;48:985-8.

81 Raber MN, Barlogie B, Latrieve J, Bedrossian C, Fritsche $\mathrm{H}$, Blumenschein $\mathrm{G}$, Ploidy, proliferative activity and estrom receptor content in human breast cancer. Cytometry 1982;3:36-41.

82 Thorud E, Fossa SD, Vaage S, et al. Primary breast cancer flow cytometry DNA pattern in relation to clinical and histopathological characteristics. Cancer 1986;57:808-11.

83 Hedley DW, Rugg CA, Gelber RD. Association of DNA index and $S$-phase fraction with prognosis of nodes positive early breast cancer. Cancer Res 1987;47:4729-35.

84 Brooks S, Camplejohn RS, Young T, Leathem T. Analyses of DNA ploidy and S-phase fraction as indicators of prognosis in breast cancer. $J$ Pathol 1989;157:164A.

85 O'Rielly SM, Camplejohn RS, Barnes DM, Millis RR, Richards MA. DNA index, S-phase fraction and prognosis in breast cancer. Br J Cancer 1989;59:825A.

86 Quirke P, Dixon MF, Clayden AD, et al. Prognostic significance of DNA aneuploidy and cell proliferation in rectal adenocarcinomas. J Pathol 1987;151:285-91.

87 Macartney JC, Camplejohn RS. DNA flow cytometry of histological material from dysplastic lesions of human gastric mucosa. J Pathol 1986;150:113-18.

88 Volm M, Mattern J, Muller T, Drings P. Flow cytometry of epidermoid lung carcinomas: Relationship of ploidy and cell cycle phases to survival. A five year follow up study. Anticancer Res 1988;8:1105-12.

89 Newton JA, Camplejohn RS, McGibbon DH. The flow cytometry of melanocytic skin lesions. $\mathrm{Br} J$ Cancer 1988;58:606-9.

90 Lloyd RV, Wilson BS, Varani J, Gaur PK, Moline S, Makari JG. Immunocytochemical characterisation of monoclonal antibody that recognises mitosing cells. $\mathrm{Am}$ Pathol 1985;121:275-83.

91 Gerdes J, Schwab U, Lemke H, Stein H. Production of monoclonal antibody reactive with a human nuclear antigen associated with cell proliferation. Int J Cancer 1983;31:13-20.

92 Gerdes J, Lemke H. Baish H, Wacker HH, Schwab U, Stein $\mathrm{H}$. Cell cycle analysis of a cell proliferation sssociated human nuclear antigen defined by the monoclonal antibody Ki67. J Immunol 1984;133:1710-6.

93 Verhuijen R, Kuijpers HJH, Schlingemann RO, et al. Ki67 detects a nuclear matrix-associated proliferationKi67 detects a nuclear matrix-associated proliferationrelated antigen. I Intracellular local

94 Verhuijen R, Kuijpers HJH, van Driel R, et al. Ki67 detects a nuclear matrix-associated proliferation-related antigen. II Localisation in mitotic cells and associated with chromosomes. J Cell Sci 1989;92:531-41.

95 Schwarting R, Gerdes J, Niehus J, Jaesche L, Stein H. Determination of the growth fraction in cell suspensions Determination of the gro the monoclonal antibody $\mathrm{Ki} 67$. J Immunol Methods 1986;90:365-71.

96 Silvestrini R, Costa A, Vereroni S, Del Bino G, Persici P. Comparative analysis of different approaches to invesComparative analysis of different approaches to

97 Veroni S, Costa A, Motta R, Giardini R, Rilke F, Silvestho labelling ini $\mathrm{R}$. Comparaclonal antibody Ki-67 in non-Hodgkin's index and mo. Haematol Oncol 1988;6:21-8.

98 lymphoma. Haematol Oncol RA, Ringus JC, Meyer JS. Thymidine labelling index and $\mathrm{Ki}-67$ growth fraction in Thymidine labelling index and

99 lesions of the breast. Am Jathol Shinozaki F, Takahash Sasaki K, Matsumura K, T suji T, Shinozaki F, Ki56 and M. Relationship between labelning tumours. Cancer 1988;62:989-93.

100 Schrape S, Jones DB, Wright DH. A comparison of three methods for the determination of the growth fraction in non-Hodgkin's lymphomas. Br J Cancer 1987;55:283-6. 
101 Falini B, Canino S, Sacchi S, et al. Immunocytochemical evaluation of the percentage of proliferating cells in pathological bone marrow and peripheral blood samples with the Ki67 and antibromo-deoxyuridine antibodies. $\mathrm{Br}$ J Haematol 1988;69:311-20.

102 Wersto RP, Herz F, Gallagher RE, Koss LG. Cell cycle dependent reactivity with the monoclonal antibody Ki67 during myeloid differentiation. Exp Cell Res 1988;179: $79-88$.

103 Sasaki K, Murakami T, Kawasaki M, Takahashi M. The cell cycle associated change of the Ki67 reactive nuclear antigen expression. J Cell Physiol 1987;133:579-84.

104 Walker RA, Camplejohn RS. Comparison of monoclonal antibody $\mathrm{Ki}-67$ reactivity with grade and DNA flow cytometry of breast carcinomas. Br J Cancer 1988;57: 281-3.

105 Baisch H, Gerdes J. Simultaneous staining of exponentially growing versus plateau phase cells with the proliferationassociated antibody $\mathrm{Ki} 67$ and propidium idiode: analysis associated antibody Ki67 and propidium idiode: analys
by flow cytometry. Cell Tissue Kinet 1987;20:387-91.

106 Dierendonck JH van, Keijezer R, van de Velde CJH, Cornelisse CJ. Nuclear distribution of the Ki67 antigen during the cell cycle: comparison with growth fraction in human breast cancer cells. Cancer Res 1989;49:2999-3006.

107 Neubauer A, Huhn D. Monoclonal antibody Ki67 as proliferation marker. Br J Haematol 1987;55:495.

108 Gerdes J, Dallenbach F, Lennert K, Stein H. Growth fractions in malignant non-Hodgkin's lymphomas as determined in situ with the monoclonal antibody Ki67. Haematol Oncol 1984;2:365-71.

109 Hall PA, Richard MA, Gregory WM, d'Adenne AJ, Lister TA, Stansfeld AG. The prognostic significance of Ki67 immunostaining in non-Hodgkin's lymphomas. J Pathol 1988;154:223-35

110 Gerdes J, Van Baarlen J, Pileri S, Schwarting R, Van Unnik JAM, Stein H. Tumour cell growth fraction in Hodgkin's disease. Am J Pathol 1987;129:390-3.

111 Falini B, Stein H, Pileri S, et al. Expression of lymphoid associated antigens on Hodgkin's and Reed-Sternberg cells of Hodgkin's disease. An immunocytochemical study of lymph node cytospins using monoclonal antibodies. Histopathology 1987;11:1229-42.

112 Lokhorst HM, Boom, SE, Terstra W, Roholl P, Gerdes J. Bast BJEG. Determination of the growth fraction in monoclonal gammopathy with the monoclonal antibody Ki67. Br J Haematol 1988;69:477-81.

113 Barnard NJ, Hall PA, Lemoine NR, Kadar NJ Proliferative index in breast carcinoma determined in situ by $\mathrm{Ki} 67$ immunostaining and its relationship to pathological and clinical variables. $J$ Pathol 1987;152:287-95.

114 Gerdes J, Lelle RJ, Pickartz H, et al. Growth fractions in breast carcinomas determined in situ with monoclonal antibody Ki67. J Clin Pathol 1986;39:977-80.

115 Franklin WA, Bibbo M, Doria MI, et al. Quantitation of estrogen receptor and $\mathrm{Ki} 67$ staining in breast carcinoma by the microTICAS Image analysis system. Analyt Quant Cytol Histol 1987;9:279-86.

116 Ueda T, Aozasa K, Tsujimoto M, et al. Prognostic significance of $\mathrm{Ki67}$ reactivity in soft tissue sarcomas. Cancer 1989;63:1607-11.

117 Burger PC, Shibata T, Kleihues P. The use of the monoclonal antibody $\mathrm{Ki67}$ in the identification of proliferating cells: Application to neuropathology. $\mathrm{Am}$ Surg Pathol 1986;10:611-17

118 Giangaspero F, Doglioni C, Rivano MT, Pileri S, Gerdes J Stein $\mathrm{H}$. Growth fraction in human brain tumours defined by the monoclonal antibody $\mathrm{Ki}-67$. Acta Neuropathol 1987;74:179-82.

119 Gatter KC, Dunnill MA, Gerdes J, Stein H, Mason DY. New approach to assessing lung tumours in man. $J$ Clin Pathol 1986;39:590-3.

120 Brown DC, Cole D, Gatter KC, Mason DY. Carcinoma of the cervix uteri: an assessment of tumour proliferation using the monoclonal antibody Ki67. $\mathrm{Br} J$ Cancer $1988 ; 57: 178-81$.

121 Shepherd NA, Richman PI, England J. Ki67 derived proliferative activity in colorectral adenocarcinoma with prognostic correlations. J Pathol 1988;155:1213-19.

122 Grogioni WF, D'Errico A, Bacci F, Mazziotti A, Gozzett G, Mancini AM. Primary liver neoplasms: evaluation of proliferative index using MoAb Ki67. J Pathol 1989;158:23-9.

123 Gerdes J, Stein H, Rivano MT, et al. Prognostic relevance of tumour cell growth fraction in malignant non-Hodgkin's lymphoma. Lancet 1987;ii:448-9.

124 Grogan TM, Lippman SM, Spier CM, et al. Independent prognostic significance of a nuclear proliferation antigen in diffuse large cell lymphomas as determined by the monoclonal antibody Ki-67. Blood 1988;71:1157-60.

125 Bouzubar N, Walker KJ, Griffiths K, et al. Ki67 immunostaining in primary breast cancer: pathological and clinical associations. Br J Cancer 1989;59:943-7.

126 Rivano MT, Falini B, Stein H, et al. Histiocytic necrotizing lymphadenitis without granulocytic infiltration (Kikuchi's lymphadenitis). Morphological and immunohistochemical study of 8 cases. Histopathology 1987;11 1013-27.

127 Gerdes J, Schwarting R, Stein $H$. The vast majority of the Reed-Sternberg cell associated antigen Kil positive cells in normal lymphoid tissue are proliferating as revealed by a double immunoenzymatic technique. J Clin Pathol 1986;39:993-7.

128 Hall PA, Greenwood RN, d'Ardenne AJ, Levison DA. In situ demonstration of renal tubular regeneration using the monoclonal antibody Ki67. Nephron 1988;49:122-5.

129 Franklin WA, McDonald GB, Stein H, et al. Immunohistological demonstration of abnormal colonic crypt cell kinetics in ulcerative colitis. Hum Pathol 1985;16: 1129-32.

130 Lalor PA, Mapp PI, Hall, Revell PA. Proliferative study of cells in the synovium as demonstrated by a monoclonal antobidy, Ki67. Rheumatol Int 1987;7:183-6.

131 Pace D, Morrison L, Bulmer JN. Proliferative activity in endometrial stromal granulocytes throughout the menstrual cycle. J Clin Pathol 1989;42:35-9.

132 Chilosi M, Menestrina F, Capelli P, et al. Immunohistochemical analysis of sarcoid granulomas. Evaluation of $\mathrm{Ki}^{+} 7^{+}$and interleukin-1 $1^{+}$cells. Am $J$ Pathol 1988;131:191-8.

133 Brown DC, Gatter KC, Dunnill MS, Mason DY. Immunocytochemical analysis of cytocentrifuged preparations; a study based upon lung tumours aspirated in vitro. Analyt Quant Cytol Histol 1989;11:140-5.

134 Kuenen-Buomester V, Blonk DI, van der Kwast Th-H. Immunocytochemical staining of proliferating cells in fine needle aspiration smears of primary and metastatic breast tumours. Br J Cancer 1988;57;509-11.

135 Wahl AF, Geis AM, Spain BH, Wong SW, Korn D, Wang TSF. Gene expression of human DNA polymerase $\alpha$ during cell proliferation and the cell cycle. Mol Cell Biol 1989;8:5016-25.

136 Tanaka S, Hu S-Z, Wang TSF, Korn D. Preparation and preliminary characterisation of monoclonal antibodies against DNA polymerase $x$. J Biol Chem 1982;257: 8386-90.

137 Bensch KG, Tanaka S, Hu S-Z, Wang TSF, Korn D. Intracellular localisation of human DNA polymerase $\alpha$ with monoclonal antibodies. J Biol Chem 1982;257: 8391-6.

138 Namikawa R, Ueda R, Suchi T, Itoh G, Ota K, Takahashi $T$. Double imunoenzymatic detection of surface phenotype of proliferating lymphocytes in situ with monoclonal antibodies against DNA polymerase $x$ and lymphocyte membrane antigens. Am J Clin Pathol 1987;87:725-31.

139 Namikawa R, Suchi T, Ueda R, et al. Phenotyping of proliferating lymphocytes in angioimmunoblastic lymphadenopathy and related lesions by the double immunoezymatic staining technique. Am J Pathol 1987;127: $279-87$.

140 Habeshaw JA, Lister TA, Stansfeld AG, Greaves MF Correlation of transferring receptor expression with histological class and outcome in non-Hodgkin's lymphoma. Lancet 1983;i:498-500.

141 Gatter KC, Brown G, Trowbridge IS, Woolston RE, Mason DY. Transferrin receptor in human tissues: their distribution and possible clinical significance. J Clin distribution and poss
Pathol 1983;36:539-45.

142 Pileri S, Gerdes J, Rivano M, et al. Immunohistochemical determination of growth fractions in human permanent cell lines and lymphoid tumours: a critical comparison of the monoclonal antibodies OKT9 and Ki67. Br J Haematol 1987;68:271-6.

143 Miyachi K, Fritzler MJ, Tan EM. Autoantibody to a nuclear antigen in proliferating cells. $J$ Immunol 1978;121:2228-34.

144 Takasaki Y, Deng J-S, Tan EM. A nuclear antigen associated with cell proliferation and blast transformation. Its distribution in synchronised cells. J Exp Med 81:154:1899-909.

145 Celis JE, Bravo R, Larsen PM, Fey SJ. Cyclin: a nuclear protein whose level correlates directly with the proliferative state of normal as well as transformed cells. Leukaemia Res 1983;8:143-57.

146 Smetana K, Gyorkey F, Chan P-K, Tan CE, Busch H. Proliferating cell nuclear antigen (PCNA) and human malignant nucleolar antigens (HMTNA) in nucleoli of human haematological malignancies. Blut 1983;46: 133-41.

147 Garcia RL, Coltrera MD, Gown AM. Analysis of proliferative grade using anti-PCNA/cyclin monoclonal proliferative grade using anti-PCNA/cyclin monoclonal
antibodies in fixed, embedded tissues. Am J Pathol 1989;134:733-9.

148 Crocker J, Nucleolar organiser regions. In: Underwood JCE, ed. Current topics in pathology: Nuclear pathology. Berlin: Springer Verlag, 1989.

149 Willaims MA, Kleinschmidt JA, Krohne G, Franke WW Argyrophilic nuclear and nucleolar proteins of Xenopus aevis oocytes identified by gel electrophoresis. Exp Cell Res 1982;137:341-51.

150 Ochs RL, Busch H. Further evidence that phosphoprotein $\mathrm{C}_{23}(110 \mathrm{kD} / \mathrm{pH} 5.1)$ is in nucleolar silver staining protein Exp Cell Res 1984;152:260-5.

151 Busch $H$. Nucleolar proteins: purification isolation and functional analyses. In: Huilica LS, ed. Chromosomal non histone proteins. Volume IV. Boca Raton, Florida: CRC Press, 1984.233-86.

152 Lischwe MA, Smetana K, Olson MOJ, Busch H. Proteins $\mathrm{C}_{23}$ and $\mathrm{B}_{23}$ are the major nucleolar silver staining proteins. Life Sci 1979;25:701-8.

153 Hernandez-Verdun D, Derenzini $M$, Bouteille $M$ Relationship between AgNOR proteins and ribosomal chromatin in situ during drug induced RNA synthesis inhibition. J Ultrastruct Res 1984;88:55-65.

154 Das BS, Rani R, Mitra AB, Luthra UK. The number of silver staining NOR's (rDNA) in lymphocytes of newborns and its relationship to human development. Mech Ageing Dev 1986;36:117-23.

155 DeCapoa A, Baldini A, Marleka P, et al. Hormone 
regulated rRNA gene activity is visualised by selective staining of NOR's. Cell Biol Int Rep 1985:9:791-6.

156 Field DH. Fitzgerald PH, Sin FYT. Nucleolar silver staining patterns related to cell cycle phase and cell generation of PHA stimulated human lymphocytes. Cytobios 1984;41:23-33.

157 Crocker J, Nar P. Nucleolar organiser regions in lymphomas. J Pathol 1987;151:111-8.

158 Crocker J, Boldy DAR, Egan MJ. How should we count AgNORS? Proposals for a standardised nomenclature. J Pathol 1989;158:189-94.

159 Hall PA, Crocker J, Watts A, Stansfeld AG. A comparison of nucleolar organiser region staining and $\mathrm{Ki}-67$ immunostaining in non-Hodgkin's lymphoma. Histopathology 1988;12:373-81.

160 Crocker J, McCartney JC, Smith PJ. Correlation between DNA flow cytometric and nucleolar organiser region data in non-Hodgkin's lymphoma. J Pathol 1988;154:151-60.

161 Guillaud P, du Manoir S, Seigneurin D. Quantitation and topographical distribution of $\mathrm{Ki} 67$ antibody labelling
during the cell cycle of normal fibroblastic (MRC-5) and during the cell cycle of normal fibroblastic (MRC-5) and
mammary tumour cell lines (MCF-7). Analyt Cell Pathol mammary tum

162 Jan-Mohamed RM, Armstrong SJ, Crocker J, Leyland MJ, Hulten MA. The relationship between numbers of interphase NORs and NOR-bearing chromosomes in non-Hodgkin's lymphoma. J Pathol 1989;158:3-7.

163 Derenzini M, Pession A, Farabegoli F, Badiali M, Dehan P. Relationship between interphasic nucleolar organiser regions and growth rate in two neuroblastoma cell lines. Am J Pathol 1989;134:925-32.

164 Egan MJ, Raafat F, Crocker J, Smith K. Nucleolar organiser regions in small cell tumours of childhood. organiser regions in small
$J$ Pathol $1987 ; 153: 275-80$.

165 Crocker J, Skilbeck N. Nucleolar organiser regionassociated protein in melanotic lesions of the skin. A quantitative study. J Clin Pathol 1987;40:885-9.

166 Smith R, Crocker J. Evaluation of nucleolar organiser region-associated proteins in breast malignancy. Histopathology 1988;12:113-26.

167 Crocker J, Ayres J, McGovern J. Nucleolar organiser regions in small cell carcinoma of the bronchus. Thorax 1987;42:972-5.

168 Morgan DW, Crocker J, Watts A, Shenoi PM. Salivary gland tumours studied by means of the AgNOR technique. Histopathology 1988;13:553-60.

169 Rowlands DC. Nucleolar organiser regions in cervical intraepithelial neoplasia. J Clin Pathol 1988;41:1200-2.

170 Derenzini M, Romagnoli T, Mingazzini P, Marinozzi V. Interphasic NOR distribution as a diagnostic parameter to differentiate benign from malignant epithelial tumours of the intestine. Virchows Arch (Pathol Anat) (in press).

171 Murray PG, Boldy DAR, Crocker J. Ayres JG. Sequential demonstration of antigens and AgNORs in frozen and paraffin sections. J Pathol 1989;159:169-72.

172 McGovern J, Crocker J. The assessment of nucleolar organiser regions in thyroid neoplasia. J Clin Pathol organiser region

173 Fallowfield ME, Cook MG. The value of nucleolar organ- iser region staining in the differential diagnosis of borderline melanocytic lesions. Histopathology 1989;14:299-304 174 Walker RA. The histopathological evaluation of nucleola organiser region proteins. Histopathology 1988;12:221-3.

175 Egan MJ, Crocker J, Raafat F, Williams D. Comparative study of the degree of differentiation of neuroblastoma and mean numbers of nucleolar organiser regions. J Clin Pathol 1988;41:527-31.

176 Aherne WA, Camplejohn RS, Wright NA. An introduction to cell population kinetics. London: Edward Arnold, 1977.

177 Aherne WA, Dunnill MS. Morphometry. London: Edward Arnold, 1982.

178 Garcia CF, Weiss LM, Lowder J, et al. Quantitation and estimation of lymphocyte subsets in tissue sections. Comparison with flow cytometry. Am J Clin Patho 1987;87:470-7

179 Schwartz BR, Pinkus G, Bacus S, Toder M, Weinberg DS Cell proliferation in non-Hodgkin's lymphomas. Digita image analysis of $\mathrm{K}_{1}-67$ antibody staining. Am J Pathol 1989;134:327-36.

180 Charpin C, Andrac L, Habibn M-C, et al. Immunodetection in fine-needle aspirates and multiparametric (SAMBA) image analysis. Receptors (monoclonal antiestrogen and antiprogesterone) and growth fraction (monotrogen and antiprogesterone) and growth fraction (monoclonal Ki67) eval

181 Paulus G, Hong LX, Atassi G, Buyssens N. Regional variations in proliferative rate and degree of differentiation in B16 melanomas. Virchows Arch / Cell Pathol 1984;46:43-52.

182 Tannock IF. The relationship between cell proliferation and the vascular system in transplanted mouse mammary tumour. Br J Cancer 1968;22:258-73.

183 Hall PA, Watt FM. Stem cells: the generation and maintenance of cellular diversity. Development 1989;106: 619-33.

184 Anonymous. Stem cells in neoplasia. [Editorial.] Lancet 1989;i:701-2.

185 Buick RN, Pollack MN. Perspectives on clonogenic tumou cells, stem cells and oncogenes. Cancer Res 1984;44: 4909-18.

186 Mackillop WJ, Ciampi A, Till JE, Buick RN. A stem cell model of human tumour growth: Implications for tumour cell clonogenic assays. JNCI 1983;70:9-16.

187 McFarlane JH, Quirke P, Bird CC. Flow cytometric analysis of DNA heterogeneity in non-Hodgkin's lymphoma. J Pathol 1986;149:236a.

188 Norton L. Implications of kinetic heterogeneity in clinica oncology. Semin Oncol 1985;12:231-49.

189 Thornton JG, Wells M, Hume WJ. Measurement of the $\mathrm{S}$-phase duration in normal and abnormal human endometrium by in vitro double labelling with bromodeoxyuridine and tritiated thymidine. J Pathol 1989;157:109-15.

190 Steel GG. Cell loss factor in the growth of human tumours Eur J Cancer 1967;30:381.

191 Wyllie AH. Apoptosis: cell death in tissue regulation. y Pathol 1987;153:313-6. 